\title{
Response of phytoplankton to an experimental fish culture in net cages in a subtropical reservoir
}

\author{
E. C. R. Bartozek ${ }^{a *}$, N. C. Bueno ${ }^{a, b}$, A. Feiden ${ }^{b, c, d}$ and L. C. Rodrigues ${ }^{e}$ \\ aPrograma de Pós-graduação em Recursos Pesqueiros e Engenharia de Pesca, Universidade Estadual do Oeste do \\ Paraná - UNIOESTE, Rua da Faculdade, 645, Jardim Santa Maria, CP 320, CEP 85903-000, Toledo, PR, Brazil \\ bPrograma de Pós-graduação em Conservação e Manejo de Recursos Naturais, Universidade Estadual do Oeste do \\ Paraná - UNIOESTE, Rua Universitária, 2069, Jardim Universitário, CEP 85819-110, Cascavel, PR, Brazil \\ ${ }^{\mathrm{c} C}$ Centro de Difusão de Desenvolvimento Tecnológico do Rio Iguaçu - CDT-Iguaçu, Capitão Leônidas Marques, PR, Brazil \\ ${ }^{\text {d} G r u p o ~ d e ~ E s t u d o s ~ d e ~ M a n e j o ~ n a ~ A q u i c u l t u r a ~-~ G E M A q, ~ U n i v e r s i d a d e ~ E s t a d u a l ~ d o ~ O e s t e ~ d o ~ P a r a n a ́ ~-~ U N I O E S T E, ~}$ \\ Rua da Faculdade, 645, Jardim Santa Maria, CP 320, CEP 85903-000, Toledo, PR, Brazil \\ 'Núcleo de Pesquisas em Limnologia, Ictiologia e Aquicultura, Universidade Estadual de Maringá - UEM, \\ Av. Colombo, 5790, B1. H-90, CEP 87020-900, Maringá, PR, Brazil \\ *e-mail: elaine.bartozek@gmail.com
}

Received: December 14, 2014 - Accepted: August 18, 2015 - Distributed: November 30, 2016

(With 4 figures)

\begin{abstract}
This study aimed to evaluate nutrients concentration and spatial-temporal changes in phytoplankton biovolume during an experimental fish culture in net cages in a lateral arm of Salto Caxias reservoir, Brazil. Two sampling stations were placed in the affected lateral arm and other two in a cageless lateral arm. Neither abiotic variables nor phytoplankton biovolume presented significant differences between the treatments. Only temporal changes were confirmed by the analysis performed. Both lateral arms were classified as oligotrophic, reflecting low influence of the net cages. Phytoplankton growth seems to be limited by nitrogen. Biovolume values were, in general, low and five major functional groups were recognized (E, F, $\mathbf{G}, \mathbf{K}$ and $\mathbf{P}$ ). In summer higher biovolume values were observed and representatives of Chlorophyceae and Cyanobacteria belonging to the functional groups $\mathbf{F}$ and $\mathbf{K}$, respectively, were the most important. In winter phytoplankton was mainly composed by Bacillariophyceae taxa from $\mathbf{P}$ group. $\mathbf{G}$ group was also restricted to winter and $\mathbf{E}$ group occurred in winter and summer. The variations recorded in phytoplankton structure appear to have been mainly influenced by seasonal changes in temperature, precipitation and nutrients availability. The effects of net cages on the abiotic variables and phytoplankton biovolume appear to have been small, probably due to the small number of net cages employed and the system dilution capacity. However, a permanent monitoring of phytoplankton is recommended, since this environment has a carrying capacity, from which the trophic state may increase.
\end{abstract}

Keywords: biovolume, environment impact, fish cultivation, functional groups, nutrients concentration.

\section{Resposta do fitoplâncton ao cultivo experimental de peixes em tanques-rede em um reservatório subtropical}

\section{Resumo}

Este estudo objetivou avaliar alterações nas variáveis abióticas e no biovolume fitoplanctônico durante o cultivo experimental de peixes em tanques-rede em um braço lateral do reservatório de Salto Caxias, Brasil. Foram selecionadas duas estações de amostragem no braço com tanques-rede e outras duas em um braço sem tanques. As variáveis abióticas e o biovolume fitoplanctônico não apresentaram diferenças significativas entre os locais estudados. Apenas mudanças temporais foram confirmadas pelas análises utilizadas. Os dois braços laterais foram classificados como oligotróficos, refletindo a baixa influência dos tanques-rede. O crescimento do fitoplâncton parece ter sido limitado principalmente por nitrogênio. Os valores de biovolume foram, em geral, baixos e cinco principais grupos funcionais foram observados $(\mathbf{E}, \mathbf{F}, \mathbf{G}, \mathbf{K}$ e P). No verão, os maiores valores de biovolume foram observados e representantes de Chlorophyceae e Cyanobacteria dos grupos funcionais $\mathbf{F}$ e K, respectivamente, se destacaram. No inverno, o fitoplâncton foi composto principalmente por táxons de Bacillariophyceae do grupo P. O grupo $\mathbf{G}$ também foi restrito ao inverno e o grupo $\mathbf{E}$ ocorreu no inverno e verão. As variações registradas na estrutura do fitoplâncton parecem ter sido principalmente influenciadas pelas mudanças sazonais de temperatura, precipitação e disponibilidade de nutrientes. Os efeitos dos tanques-rede sobre as variáveis abióticas e biovolume fitoplanctônico parecem ter sido pequenos, provavelmente devido ao pequeno número de tanques utilizados e a capacidade de diluição do sistema. Entretanto, o monitoramento permanente do fitoplâncton é recomendado, uma vez que este ambiente possui uma capacidade de suporte, a partir da qual o estado trófico pode aumentar.

Palavras-chave: biovolume, impacto ambiental, cultivo de peixes, grupos funcionais, concentração de nutrientes. 


\section{Introduction}

Fish cultivation in net cages has been stimulated by the Brazilian government policies by consider it an alternative to food production (Alves and Baccarin, 2007). Moreover, the environmental agencies and hydroelectric companies consider this activity an alternative to reduce pressure on natural stocks and generate work for artisanal fishermen (Agostinho et al., 2007; Dias et al., 2012).

However, this culture system can generate impacts on biological communities and water quality due to the nutrients input into the system, particularly phosphorus and nitrogen, resulting in eutrophication (Guo et al., 2009; Borges et al., 2010; Gorlach-Lira et al., 2013). Changes in the phytoplankton community composition and increase in biovolume, particularly Cyanobacteria, have been widely recorded in reservoirs and represents a global problem for these environments (Diaz et al., 2001; Figueredo and Giani, 2005; Burford and O'Donohue, 2006; Borges et al., 2010).

Despite several studies on the ecology of phytoplankton in tropical and subtropical reservoirs (Silva et al., 2005; Fonseca and Bicudo, 2011; Teixeira de Oliveira et al., 2011; López et al., 2012; Dantas et al., 2012; Hu et al., 2013), few have focused on the effects of fish farming in net cages on phytoplankton community. These effects are directly dependent on the magnitude of the production system and environment carrying capacity. In general, reduction of water transparency and increase of nitrogen, phosphorus, conductivity and phytoplankton density, mainly Cyanobacteria, were observed (Figueredo and Giani, 2005; Guo et al., 2009; Borges et al., 2010; Sipaúba-Tavares et al., 2014). However, increase in water transparency and decrease in phytoplankton biomass, substantially Cyanobacteria, was recorded by Torres et al. (2016) due to grazing by the omnivorous filter-feeding fish Nile tilapia (Oreochromis niloticus Linnaeus, 1758). Therefore, the impacts caused by fish cultivation on the environment and phytoplankton have not been fully elucidated yet, requiring further studies to understand its real effects.

Besides the availability of nutrients, phytoplankton composition and biovolume are also influenced by other factors such as temperature, light, stability of the water column and variations in the level of the reservoir due to the dam operation (Nogueira, 2000; Borges et al., 2008; Becker et al., 2010). Thus, phytoplankton can be used as an efficient tool to investigate spatial and temporal changes in reservoirs (Reynolds et al., 2002; Padisák et al., 2006), allowing an effective knowledge of the environment conditions (Brasil and Huszar, 2011; Dantas et al., 2012), such as succession and eutrophication processes.

The approach by grouping phytoplankton in functional groups, proposed by Reynolds et al. (2002) and improved by Padisak et al. (2009), has been widely used worldwide in ecological and monitoring purposes (Becker et al., 2010; Xiao et al., 2011; Crossetti et al., 2013). Since species are grouped according to their morpho-physiological features, it is expected that these groups will respond, for example, to changes in the mixing regime and nutrients availability, simplifying the complexity of the ecosystem (Salmaso et al., 2015).

The present study aimed to analyze spatial and temporal variations of abiotic variables and phytoplankton biovolume in an experimental system of fish farming in net cages. The tested hypotheses were that the fish cultivation (i) reduces water transparency and dissolved oxygen (ii) increases nutrient concentrations and (iii) increases phytoplankton biovolume, especially Cyanobacteria and, consequently, changes the trophic state.

\section{Material and Methods}

Salto Caxias reservoir is the last in a cascade of five large impoundments in Iguaçu River, a 1,320 Km long river and one of the most important tributaries of Paraná River. The reservoir has $142 \mathrm{Km}^{2}$ of surface area and 3,573 $\mathrm{Km}^{3}$ of volume. Water residence time is estimated in 32.5 days and shows a dendritic pattern of margin development (Ribeiro et al., 2005). The Iguaçu River basin has a wet subtropical climate (Cfa), with well-defined seasons along the year. Rainfall is usually well spread throughout the year, however it is fewer in autumn and winter than in spring and summer. The average annual rainfall ranges from 1,600 to $1,800 \mathrm{~mm}$ and the average annual temperature is $19-20{ }^{\circ} \mathrm{C}$ (Maack, 2002).

This study was carried out in two lateral arms located on the right-hand margin of the reservoir's transition region (Figure 1). The larger arm is comprised by the Jacutinga River and the smaller one by an unnamed stream. The area surrounding the reservoir is dominated by grasslands and small areas of secondary forest, with small rural properties and the predominance of family farming (Lima et al., 2005).

The study was accomplished in an experimental net cages cultivation of silver catfish (Rhamdia voulezi) and surubim do Iguaçu (Steindachneridion melanodermatum). In the limnetic zone of the first arm three sets of ten net cages were transversally settled, each one with $4 \mathrm{~m}^{3}$ and 60 adult fishes. Fishes were fed with a floating feed (32\% of protein, $1.5 \%$ of phosphorus and $5.2 \%$ of nitrogen) twice a day using the technique of supply ad libidum. The second arm, comprised by the Jacutinga River, was considered without influence of the net cages. Two sampling stations (N1 and N2) were stablished beside the sets of net cages and around $200 \mathrm{~m}$ apart from each other. Two another stations were placed in the cageless arm (C1 and C2) and also at $200 \mathrm{~m}$ apart from each other.

Samples were taken at the subsurface $(20 \mathrm{~cm}$ depth) in the limnetic region, bimonthly from September 2010 to July 2011. Phytoplankton samples were preserved using Lugol's solution. Water temperature (WT) and dissolved oxygen (DO) were measured with portable digital potentiometers. Euphotic zone $\left(\mathrm{Z}_{\text {eu }}\right)$ was calculated as 2.7 times the Secchi disk depth (Cole, 1994). Euphotic zone:maximum depth ratio $\left(\mathrm{Z}_{\mathrm{eu}}: \mathrm{Z}_{\max }\right)$ was used as an index of light availability in the water column. Turbidity (Turb), $\mathrm{pH}$ and concentrations of dissolved total phosphorus (P-DTP; Mackereth et al., 1978), soluble reactive phosphorus 


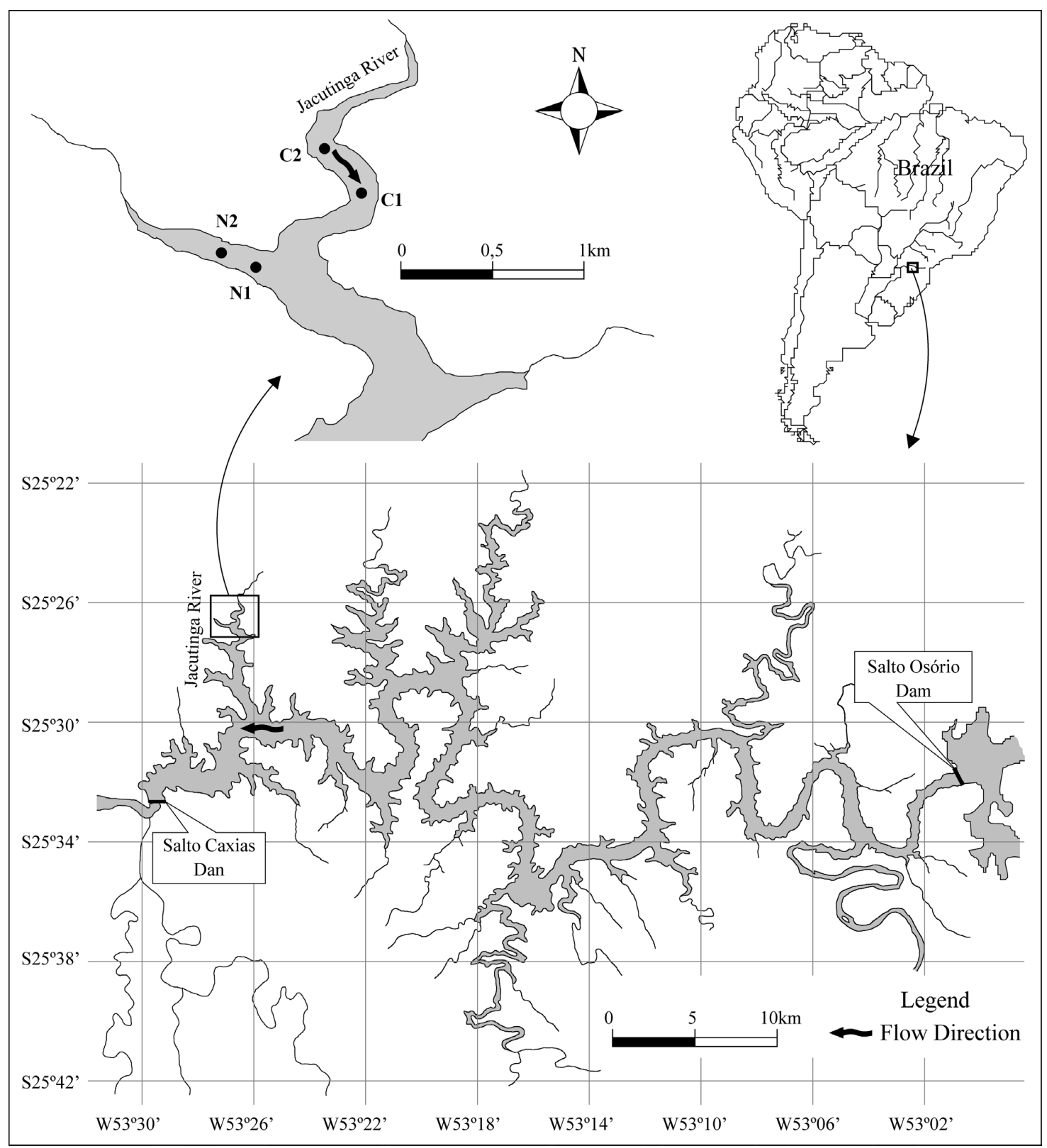

Figure 1. Map showing the localization of the sampling stations in Salto Caxias Reservoir (N1 and N2: lateral arm with net cages, $\mathrm{C} 1$ and $\mathrm{C} 2$ : lateral arm without net cages).

(P-SRP; Mackereth et al., 1978), nitrite (N-NO${ }_{2}^{-}$; Strickland

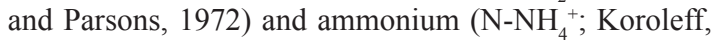
1976) were determined. Wind speed values (Win), air temperature (AT) and precipitation (Pre) were provided by the Meteorological Institute of Paraná (Simepar) and records were obtained from Salto Caxias station. In statistical and multivariate analysis we used, for rainfall, the sum of the three days preceding the sampling, since phytoplankton presents a rapid response to environment changes.

Dissolved inorganic nitrogen (DIN) was calculated as the sum of nitrite and ammonium and DIN:SRP ratio was used as an index to estimate nutrient limitation for phytoplankton growth in the systems (Kosten et al., 2009). If DIN:SRP ratio < 13 it is considered limited by N; and above 50 it is limited by $P$.

Phytoplankton density was estimated according to Utermöhl (1958) and biovolume by multiplying the density of different taxa by their respective volumes, as recommended by Sun and Liu (2003). Trophic state was determined following the Vollenweider (1968) criteria. Species with contribution higher than $1 \%$ to the total phytoplankton biovolume were grouped in Functional 
Groups (FG) according to Reynolds et al. (2002) and Padisák et al. (2009).

Nonparametric tests were used to test significant differences in the abiotic variables. A Wilcoxon-Mann-Whitney test was applied to test significant differences between the treatments (locals with and without net cages) and a Kruskal-Wallis test was applied to test significant differences between seasons (winter - September 2010, May and July 2011 and summer - November 2010, January and March 2011). The same analysis was also applied to test significant differences in biovolume and functional groups values. These analyses were performed using R software, packages vegan and agricolae (R DEVELOPMENT CORE TEAM, 2008). The relationships between the abiotic data and phytoplankton biovolume were analyzed through canonical correspondence analysis (CCA; Ter Braak, 1986) using Pc-Ord 4.0 (MacCune and Mefford, 1999). Previously a principal component analysis was performed to choose the most important variables and avoid collinearity. Species with contribution $\geq 1 \%$ per sampling were used in CCA. Abiotic and biotic data were transformed by $\log \mathrm{x}+1$.

\section{Results}

No significant differences in the abiotic variables were observed between the treatments (local with and without net cages), however significant temporal differences occurred in water temperature, dissolved oxygen, turbidity, P-DTP, P-SRP, ${\mathrm{N}-\mathrm{NO}_{2}}^{-}$and $\mathrm{N}-\mathrm{NH}_{4}{ }^{+}$. The highest rainfall was observed in summer (from October 2010 to March 2011) and the lowest in winter (September 2010 and April to August 2011) (Figure 2). However, in July 2011, despite being a month of drought, heavy rainfall occurred, especially in the days prior to the sampling and a clear pattern between dry and rainy seasons wasn't observed. High light availability was observed in most of the period as demonstrated by the values of $Z_{\text {eu }}: Z_{\text {max }}$ (Table 1$)$. Turbidity was significantly higher in summer $(p=0.011)$, mainly in stations $\mathrm{C} 1$ and $\mathrm{C} 2$. Water temperature presented significant differences in January and March $(p=0.001)$ and lower

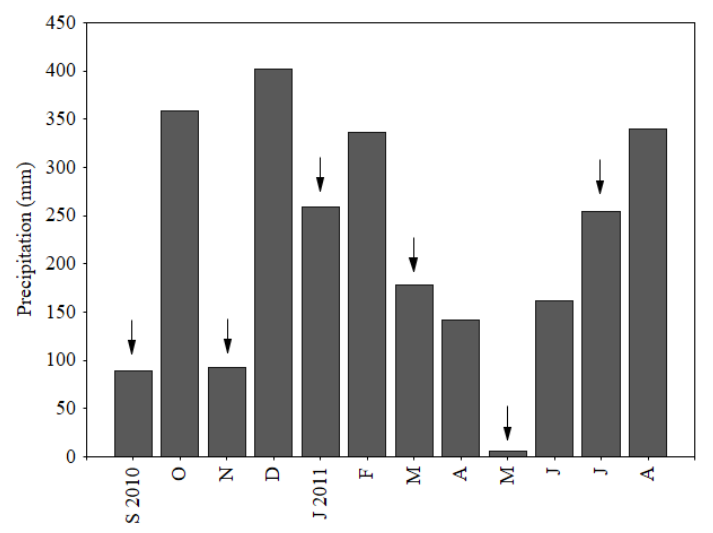

Figure 2. Precipitation values from September 2010 to July 2011. Sampling days are indicated by arrows. values occurred in July 2011. Values of dissolved oxygen were significantly higher $(p=0.009)$ in July.

The $\mathrm{pH}$ values didn't present high variation during the study period and the lowest values were observed in stations $\mathrm{C} 1$ and $\mathrm{C} 2$ in September. $\mathrm{N}-\mathrm{NH}_{4}{ }^{+}$concentrations presented differences $(p=0.001)$ in September and November, January and May and July and March. N-NO ${ }_{2}^{-}$presented higher values in summer $(\mathrm{p}=0.001)$, specially is station C1 in March. Precipitation, turbidity, P-DTP, P-SRP, $\mathrm{N}-\mathrm{NH}_{4}^{+}$and $\mathrm{N}_{-} \mathrm{NO}_{2}^{-}$values showed highest coefficients of variation throughout the study period. Considering DIN:SRP ratio, phytoplankton growth in the two arms seems to be limited mainly by N (DIN:SRP ratio $\sim 2.68$ ), except stations $\mathrm{C} 2$ and N2 in May, where a co-limitation by $\mathrm{N}$ and $\mathrm{P}$ appears to be occurred.

In relation to the phytoplankton composition, 206 taxa were inventoried during the study period. The greatest contribution groups were Cyanobacteria (32\%), Bacillariophyceae (29\%) Zygnemaphyceae (18\%) and Chlorophyceae (15\%). Spatial significant differences were not observed in biovolume values and, due to the low biovolume values, both arms were classified as oligotrophic. On the other hand, significant temporal changes occurred. Summer, particularly March, presented higher mean values of biovolume $\left(1.87 \mathrm{~mm}^{3} \mathrm{~L}^{-1}\right)$ with greater contribution of Cyanobacteria $(\mathrm{p}=0.000)$ and Chlorophyceae $(\mathrm{p}=0.001)$ species, such as Aphanocapsa delicatissima West \& West, A. holsatica Cronberg \& Komárek, Eutetramorus fottii (Hindák) Komárek and E. planctonicus (Korshikov) Bourrelly (Figure 3a and b). In winter Bacillariophyceae species predominated and July presented significant higher biovolume values $(\mathrm{p}=0.01)$. It was mainly represented by Aulacoseira granulata (Ehrenberg) Simonsen and A. pusilla (Meister).

From a total of 16 functional groups identified, five together best contributed to the total values of biovolume $(95.32 \%)$ and three of them showed temporal significant differences (Figure 3c and d). F group (mainly represented by Eutetramorus fottii) and $\mathbf{K}$ (Aphanocapsa delicatissima and $A$. holsatica) were the most important in summer $(\mathrm{p}=0.001)$, with significantly higher biovolume values in January and March, respectively. G group (Volvox aureus Ehrenberg) presented higher biovolume in May $(\mathrm{p}=0.05)$. E group (Mallomonas spp.) and $\mathbf{P}$ (Aulacoseira spp.) were the most important groups in winter.

The canonical correspondence analysis (CCA) performed with five environmental variables and 29 species presented significant scores for the first two axes $(\mathrm{p}<0.05)$, according to the Monte Carlo test (Figure $4 \mathrm{a}$ and $\mathrm{b}$ ), indicating significant correlations between environmental variables and phytoplankton. These two axes explained together $29 \%$ of the total data variability. CCA diagram presented differences in the temporal distribution of sampling units and phytoplankton biovolume, however, significant spatial differences were not observed.

According to the first axis of CCA, P-DTP (0.83) and $\mathrm{N}_{-} \mathrm{NO}_{2}^{-}(0.79)$ were the most important variables for its ordination, separating September 2010, January, March and May 2011 to the right when, in general, 
Table 1. Mean values and coefficients of variation for precipitation (Pre: $\mathrm{mm}$ ), wind speed (Win: $\mathrm{m} \mathrm{s}^{-1}$ ), maximum zone $\left(Z_{\max }: m\right)$, euphotic zone $\left(Z_{\mathrm{eu}}: \mathrm{m}\right), \mathrm{Z}_{\mathrm{eu}}: \mathrm{Z}_{\max }$ : euphotic zone: maximum zone ratio, air temperature (AT: $\left.{ }^{\circ} \mathrm{C}\right)$, water temperature (WT: ${ }^{\circ} \mathrm{C}$ ), dissolved oxygen (DO: $\mathrm{mg} \mathrm{L}^{-1}$ ), turbidity (Turb.: NTU), soluble reactive phosphorus (P-SRP: $\mu \mathrm{g} \mathrm{L}^{-1}$ ), dissolved total phosphorus (P-DTP: $\left.\mu \mathrm{g} \mathrm{L}^{-1}\right)$, ammonium $\left(\mathrm{N}_{-} \mathrm{NH}_{4}^{+}: \mu \mathrm{g} \mathrm{L}^{-1}\right)$, nitrite $\left(\mathrm{N}_{-} \mathrm{NO}_{2}^{-}: \mu \mathrm{g} \mathrm{L}^{-1}\right)$ and dissolved inorganic nitrogen:soluble reactive phosphorus ratio measured in the two tributaries of Salto Caxias reservoir from September 2010 to July 2011. N1 and N2: arm with net cages, C1 and C2: cageless arm.

\begin{tabular}{|c|c|c|c|c|c|c|c|c|c|c|c|c|c|}
\hline Stations & Pre & $\mathbf{Z}_{\max }$ & $\mathbf{Z}_{\mathrm{eu}}$ & $\begin{array}{l}Z_{\text {eu }}: \\
Z_{\max }\end{array}$ & $\mathbf{T}_{\mathrm{w}}$ & DO & Turb & pH & P-DTP & P-SRP & $\mathrm{N}-\mathrm{NH}_{4}^{+}$ & $\mathrm{N}-\mathrm{NO}_{2}^{-}$ & DIN:SRP \\
\hline \multicolumn{14}{|l|}{ N1 } \\
\hline Sep & 0.0 & 9.6 & 9.6 & 1.0 & 23.9 & 6.7 & 2.1 & 7.1 & 24.2 & 47.7 & 47.26 & 0.43 & 1.00 \\
\hline Nov & 50.8 & 9.9 & 7.9 & 0.8 & 23.5 & 6.3 & 3.1 & 7.1 & 8.7 & 50.4 & 46.16 & 4.18 & 1.75 \\
\hline Jan & 62.2 & 9.9 & 9.9 & 1.0 & 28.2 & 5.6 & 0.3 & 7.3 & 3.8 & 35.2 & 28.57 & 6.63 & 1.64 \\
\hline Mar & 0.0 & 10.7 & 9.3 & 0.9 & 28.5 & 6.3 & 0.8 & 7.6 & 0.5 & 8.9 & 0.0 & 8.86 & 0.26 \\
\hline May & 0.2 & 11.2 & 8.0 & 0.7 & 24.2 & 5.9 & 1.2 & 7.2 & 0.5 & 28.6 & 28.57 & 0.0 & 5.60 \\
\hline Jul & 81.0 & 7.8 & 7.1 & 0.9 & 20.0 & 7.5 & 0.0 & 7.3 & 3.8 & 24.7 & 2.21 & 0.0 & 0.09 \\
\hline \multicolumn{14}{|l|}{ N2 } \\
\hline Sep & 0.0 & 6.5 & 6.5 & 1.0 & 21.5 & 6.7 & 1.7 & 7.0 & 25.0 & 45.5 & 45.06 & 0.43 & 1.13 \\
\hline Nov & 50.8 & 4.2 & 4.2 & 1.0 & 23.9 & 6.2 & 2.6 & 7.1 & 13.6 & 58.0 & 53.85 & 4.18 & 1.44 \\
\hline Jan & 62.2 & 4.2 & 4.2 & 1.0 & 28.7 & 6.5 & 0.8 & 7.3 & 4.6 & 34.8 & 28.57 & 6.23 & 1.33 \\
\hline Mar & 0.0 & 5.2 & 5.2 & 1.0 & 28.0 & 5.6 & 0.4 & 7.5 & 2.2 & 7.9 & 0.0 & 7.92 & 0.14 \\
\hline May & 0.2 & 5.5 & 5.5 & 1.0 & 24.4 & 6.1 & 0.9 & 7.1 & 1.3 & 6.9 & 5.51 & 1.36 & 1.97 \\
\hline Jul & 81.0 & 5.5 & 5.5 & 1.0 & 19.7 & 7.5 & 0.0 & 7.2 & 3.0 & 2.2 & 24.74 & 0.0 & 1.20 \\
\hline \multicolumn{14}{|l|}{$\mathrm{C} 1$} \\
\hline Sep & 0.0 & 10.8 & 10.8 & 1.0 & 23.3 & 6.2 & 2.2 & 6.2 & 20.9 & 62.8 & 62.64 & 0.12 & 1.96 \\
\hline Nov & 50.8 & 9.4 & 8.9 & 1.0 & 24.4 & 6.2 & 6.2 & 7.2 & 8.7 & 63.8 & 57.7 & 6.05 & 2.10 \\
\hline Jan & 62.2 & 9.4 & 7.3 & 0.8 & 29.1 & 7.0 & 0.7 & 7.7 & 4.6 & 79.9 & 73.95 & 5.96 & 4.17 \\
\hline Mar & 0.0 & 10.9 & 10.9 & 1.0 & 28.1 & 5.7 & 0.8 & 7.0 & 4.6 & 12.6 & 0.0 & 12.61 & 0.24 \\
\hline May & 0.2 & 10.6 & 9.2 & 0.9 & 24.0 & 5.6 & 1.1 & 7.3 & 0.5 & 54.8 & 54.39 & 0.52 & 15.79 \\
\hline Jul & 81.0 & 10.6 & 7.8 & 0.7 & 20.7 & 7.4 & 0.0 & 7.3 & 3.8 & 49.3 & 48.91 & 0.43 & 1.43 \\
\hline \multicolumn{14}{|l|}{$\mathrm{C} 2$} \\
\hline Nov & 50.8 & 8.0 & 8.0 & 1.0 & 24.8 & 6.3 & 6.3 & 7.2 & 4.6 & 43.4 & 39.01 & 4.33 & 1.64 \\
\hline Jan & 62.2 & 6.3 & 6.1 & 1.0 & 29.6 & 6.5 & 0.4 & 7.4 & 4.6 & 42.9 & 42.58 & 5.14 & 1.78 \\
\hline Mar & 0.0 & 4.0 & 4.0 & 1.0 & 29.0 & 5.1 & 1.4 & 7.1 & 4.6 & 53.1 & 45.06 & 8.08 & 0.67 \\
\hline May & 0.2 & 5.6 & 5.6 & 1.0 & 25.2 & 6.1 & 0.8 & 7.1 & 0.5 & 26.5 & 25.83 & 0.52 & 14.2 \\
\hline Jul & 81.0 & 5.6 & 4.1 & 0.7 & 20.8 & 7.4 & 2.6 & 6.3 & 7.0 & 2.8 & 2.75 & 0.0 & 0.11 \\
\hline CV (\%) & 101.4 & 32.3 & 30.5 & 11.3 & 12.7 & 10.3 & 108.0 & 4.8 & 56.5 & 107.5 & 67.9 & 100.6 & 1.52 \\
\hline
\end{tabular}

higher values of these nutrients were observed. Groups J, represented by Encyonema silesiacum (Bleisch) Mann and $\mathbf{D}$ (Scenedesmus sp.) were related to September. Groups Lo, represented by Chroococcus minutus (Kützing) Nägele, K (Aphanocapsa spp.), F (Eutretamorus fottii), $\mathbf{Z}$ (Synechococcus sp.) were related to March. Groups Y (Cryptomonas sp.) and $\mathbf{G}$ (Volvox aureus Ehrenberg) occurred only in May. In the second axis, November 2010, January and July 2011 were grouped in the inferior portion of the diagram influenced by higher values of precipitation $(-0.98)$, dissolved oxygen $(-0.61)$ and $\mathrm{N}_{-} \mathrm{NH}_{4}{ }^{+}(-0.40)$. In these months, the main functional groups were $\mathbf{D}, \mathbf{F}$, S1 (Pseudanabaena limnetica [Lemmermann] Komárek), A (Spicaticribra rudis [Tremarin, Ludwig, Becker and Torgan] Tuji, Leelahakriengkrai and Peerapornpisal), J, MP (Eunotia sp.), P, E and F.

\section{Discussion}

The analysis of both abiotic and biotic variables demonstrated a temporal heterogeneity of the ecosystem. The magnitude of the effects of cage culture in the ecosystem depends primarily on the intensity of fish production, the residence time of the water and the environmental carrying capacity to assimilate nutrients input (Guo and Li, 2003; Kaggwa et al., 2011). These effects are generally stronger in water bodies with low water removal. Apparently, in this study, once few net cages were used, seasonality seems to have assumed important relevance in the environmental structuration as reported for tropical and subtropical reservoirs (Diaz et al., 2001; Silva et al., 2005; Araripe et al., 2006; Alves and Baccarin, 2007; Nogueira et al., 2010).

Despite of the low number of net cages employed, studies on the impacts of fish farming in water quality 
(a)
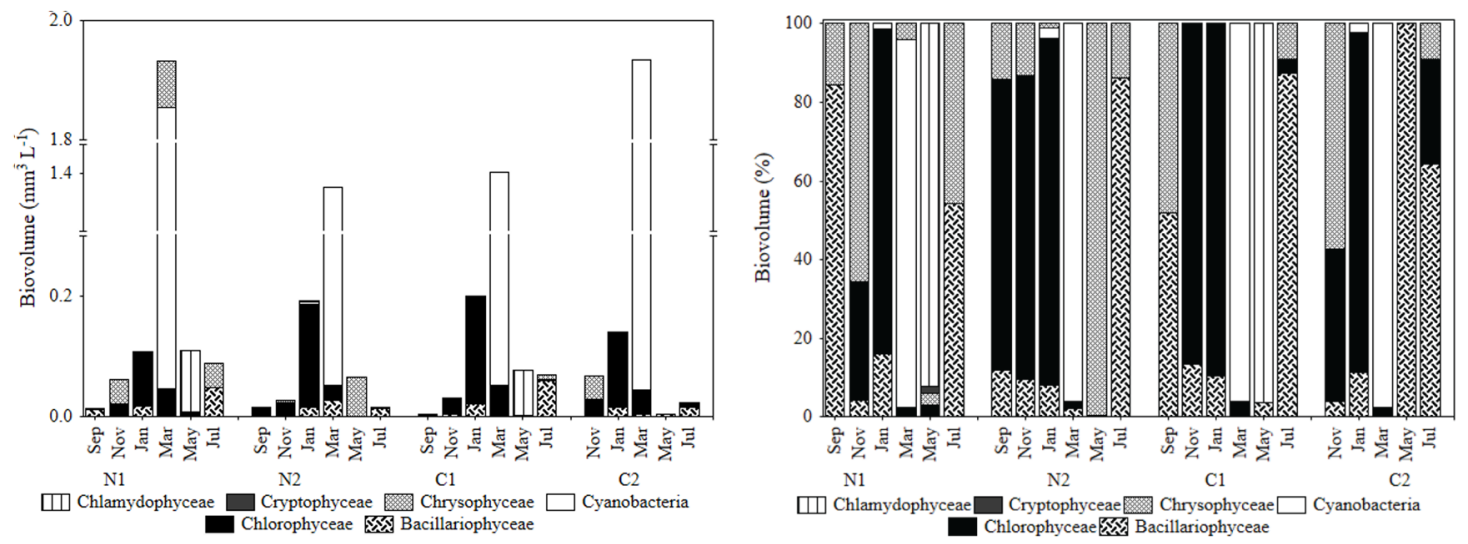

(c)
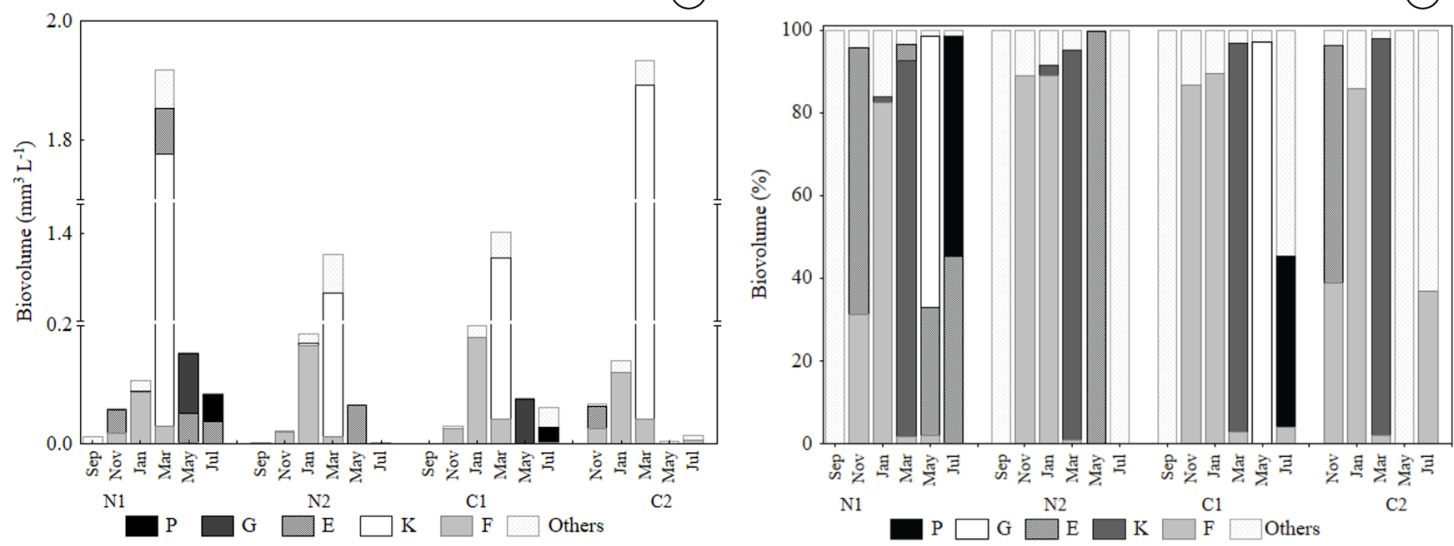

Figure 3. Values of phytoplankton biovolume registered in Salto Caxias reservoir in the four sampling stations from September 2010 to July 2011. (a) phytoplankton biovolume by Class; (b) relative biovolume (\%) by Class; (c) phytoplankton biovolume by functional groups; (d) relative biovolume (\%) by functional groups. Sep-September, Nov-November, Jan-January, Mar-March, May, Jul-July.

demonstrated increase of phosphorus and nitrogen and reduction of dissolved oxygen and water transparency (Guo and Li, 2003; Guo et al., 2009; Kaggwa et al., 2011; Sipaúba-Tavares et al., 2014). Borges et al. (2010), in an experiment with tilapia (Oreochromis niloticus L.) in net cages, in a Brazilian subtropical reservoir (Rosana Reservoir), observed an increase in total nitrogen and ammonium concentrations after the installation of the net cages.

The studied system were, in general, characterized by relatively low nutrients concentration and phytoplankton biovolume, indicating an oligotrophic condition, according to the Vollenweider (1968) criteria. In addition, nitrogen seems to be the limiting nutrient for phytoplankton growth, as already demonstrated for sub/tropical ecosystems (Jeppesen et al., 2007). However, for a long time, phosphorus was believed to be the main limiting nutrient in freshwaters. More recently, processes of limitation by both phosphorus and nitrogen has been observed and they are related to the watershed uses and geographical location of the reservoir (Kosten et al., 2009; Abell et al., 2010; Rangel et al., 2012).

Phytoplankton functional group approach has been widely used in several ecological studies in lakes and reservoirs, since it allows reducing the number of biological variables in the aquatic ecosystem (Becker et al., 2010; Xiao et al., 2011; Crossetti et al., 2013). In winter, the lowest temperatures mainly favored the development of diatoms such as Aulacoseira granulata, grouped in the $\mathbf{P}$ group, generally associated to eutrophic and mixed environments. The reduced depth $(\sim 8 \mathrm{~m})$ in both arms contributes to maintain vertical circulation allowing the resuspension of diatoms. Meroplanktonic diatoms such as Aulacoseira spp. have life cycles closely related to the mixing of the water column (Lund, 1965) and are common components of the plankton in turbulent environments (Nogueira, 2000; Bovo-Scomparin and Train, 2008; Rodrigues et al., 2009; Borges and Train, 2009).

Higher values of phytoplankton biovolume occurred in summer period due to the presence of Chlorophyceae and Cyanobacteria, possibly favored by higher light availability 



Figure 4. Scores dispersion of the sampling stations (a) and phytoplankton biomass; (b) along the first two Canonical Correspondence Analysis (CCA) axes. Codes are available in Table 1 and Figure 3.

and precipitation which increases the input of allochthonous nutrients (Nogueira, 2000; Silva et al., 2005; Borges et al., 2008). The most important functional groups found in the summer period ( $\mathbf{F}$ and $\mathbf{K}$ ) are generally related to shallow nutrient-rich water columns with good light availability and higher temperatures (Huszar et al., 2000; Komárek, 2003; Sant'Anna et al., 2006). These groups have been frequently reported as dominants in tropical shallow lakes and reservoirs, usually favored by the stability of the water column, light and nutrients availability (Kruk et al., 2002; Silva et al., 2005; Moura et al., 2007; Dantas et al., 2008; Crossetti et al., 2013).
The $\mathbf{F}$ functional group is associated to environments with high water transparency, meso to eutrophic and with deep mixing zone (Reynolds et al., 2002; Padisák et al., 2006, 2009). The great extension of the euphotic zone probably favored the occurrence of the $\mathbf{F}$ group, however, nutrients availability were a limiting factor for the development of expressive populations.

The $\mathbf{K}$ functional group comprises mainly picoplanktonic colonial cyanobacteria without aerotopes. They are favored by periods of water column stability that can explain its higher biovolume values in March 2011. Furthermore, Reynolds et al. (2002) highlighted that such picoplanktonic species have high surface/volume ratio that, therefore, 
represents an adaptive advantage in environments with nutrients limitation. In addition, the small size of the cells and the presence of mucilaginous sheath contribute to the maintenance of individuals in the water column (Reynolds, 2006, 2007; Brasil and Huszar, 2011). A similar pattern was observed by Becker et al. (2010), where the reservoir was dominated in summer by cyanobacteria from $\mathbf{K}$ group and, secondary, by green algae from $\mathbf{F}$ group favored by long periods of stratification and high light availability.

The E functional group, with occurrence in both summer and winter periods, is related to shallow and oligotrophic water bodies. The $\mathbf{G}$ group, registered only in May, is associated to nutrient-rich and stable water columns (Reynolds et al., 2002; Padisák et al., 2009). However, this motile organism combines the presence of flagella to the large cell volume to escape from moderate to low turbulent intensities (Reynolds, 2006).

Our hypotheses were not supported, because no significant changes were observed in the abiotic features and phytoplankton biovolume in the arm influenced by the fish farming system, probably due to the low number of net cages and fish employed. However, the occurrence of potentially toxigenic Cyanobacteria during the experiment suggests a potential risk that the fish cultivation can lead to the aquatic ecosystem. We verified that the seasonality, mainly characterized by changes in temperature, light availability and precipitation, were important factors for the phytoplankton structure. The water flow has permitted, so far, a sustainable production of fish due to its ability to dilute the nutrients input (Diaz et al., 2001). However, a permanent monitoring of phytoplankton is recommended, since this environment has a carrying capacity, from which the trophic state may increase.

\section{Acknowledgements}

We would like to thank the Coordenação de Aperfeiçoamento de Pessoal de Nível Superior - CAPES for funding the Masters Degree for the first author and the project CAPES/PNPD 2009 n. 02893/09-6. We are also very grateful to Dra Iraúza Arroteia Fonseca for her valuable help in the identification of Cyanobacteria taxa.

\section{References}

ABELL, J.M., ÖZKUNDAKCI, D. and HAMILTON, D.P., 2010. Nitrogen and Phosphorus limitation of phytoplankton growth in New Zealand lakes: implications for eutrophication control. Ecosystems, vol. 13, no. 7, pp. 966-977. http://dx.doi.org/10.1007/ s10021-010-9367-9.

AGOSTINHO, A.A., GOMES, L.C. and PELICICE, F.M., 2007. Ecologia e manejo de recursos pesqueiros em reservatórios do Brasil. Maringá: EDUEM.

ALVES, R.C.P. and BACCARIN, A.E., 2007. Efeito da produção de peixes em tanques-rede sobre sedimentação de material em suspensão e de nutrientes no córrego da Arribada (UHE Nova Avanhandava, baixo rio Tiête, SP). In: M.G. NOGUEIRA, R. HENRY and A. JORCIN. Ecologia de reservatórios: impactos potenciais, ações de manejo e sistemas em cascata. São Carlos: RiMa, pp. 329-347.

ARARIPE, M.N.B.A., SEGUNDO, L.F.F. and LOPES, J.B., 2006. Efeito do cultivo de peixes em tanques rede sobre o aporte de fósforo para o ambiente. Revista Cientifica de Produção Animal, vol. 8 , no. 2 , pp. $56-65$.

BECKER, V., CAPUTO, L., ORDÓÑEZ, J., MARCÉ, R., ARMENGOL, J., CROSSETTI, L.O. and HUSZAR, V.L.M., 2010. Driving factors of the phytoplankton functional groups in a deep Mediterranean reservoir. Water Research, vol. 44, no. 11, pp. 3345-3354. http://dx.doi.org/10.1016/j.watres.2010.03.018. PMid:20398914.

BORGES, P.A. and TRAIN, S., 2009. Phytoplankton diversity in the Upper Paraná River floodplain during two years of drought (2000 and 2001). Brazilian Journal of Biology $=$ Revista Brasileira de Biologia, vol. 69, no. 2, suppl., pp. 637-647. http://dx.doi. org/10.1590/S1519-69842009000300018. PMid:19738970.

BORGES, P.A.F., TRAIN, S. and RODRIGUES, L.C., 2008. Spatial and temporal variation of phytoplankton in two subtropical Brazilian reservoirs. Hydrobiologia, vol. 607, no. 1, pp. 63-74. http://dx.doi.org/10.1007/s10750-008-9367-3.

BORGES, P.A.F., TRAIN, S., DIAS, J.D. and BONECKER, C.C., 2010. Effects of fish farming on plankton structure in a Brazilian tropical reservoir. Hydrobiologia, vol. 649, no. 1, pp. 279-291. http://dx.doi.org/10.1007/s10750-010-0271-2.

BOVO-SCOMPARIN, V.M. and TRAIN, S., 2008. Long-term variability of the phytoplankton community in an isolated floodplain lake of the Ivinhema River State Park, Brazil. Hydrobiologia, vol. 610, no. 1, pp. 331-344. http://dx.doi.org/10.1007/s10750008-9448-3.

BRASIL, J. and HUSZAR, V.L.M., 2011. O papel dos traços funcionais na ecologia do fitoplâncton continental. Oecologia Australis, vol. 15, no. 4, pp. 799-834. http://dx.doi.org/10.4257/ oeco.2011.1504.04.

BURFORD, M.A. and O'DONOHUE, M.J., 2006. A comparison of phytoplankton community assemblages in artificially and naturally mixed subtropical water reservoirs. Freshwater Biology, vol. 51, no. 5, pp. 973-982. http://dx.doi.org/10.1111/j.13652427.2006.01536.x.

COLE, G.A., 1994. Text book of limnology. Illinois: Waveland Press.

CROSSETTI, L.O., BECKER, V., CARDOSO, L.S., RODRIGUES, L.R., COSTA, L.S. and MOTTA-MARQUES, D., 2013. Is phytoplankton functional classification a suitable tool to investigate spatial heterogeneity in a subtropical shallow lake? Limnologica, vol. 43, no. 3, pp. 157-163. http://dx.doi. org/10.1016/j.limno.2012.08.010.

DANTAS, E.W., BITTENCOURT-OLIVEIRA, M.C. and MOURA, A.N., 2012. Dynamics of phytoplankton associations in three reservoirs in northeastern Brazil assessed using Reynolds' theory. Limnologica, vol. 42, no. 1, pp. 72-80. http://dx.doi.org/10.1016/j. limno.2011.09.002.

DANTAS, E.W., MOURA, A.N., BITTENCOURT-OLIVEIRA, M.C., ARRUDA NETO, J.D.T. and CAVALCANTI, A.D.C., 2008. Temporal variation of the phytoplankton community at short sampling intervals in the Munduaú reservoir, Northeastern Brazil. Acta Botanica Brasílica, vol. 22, no. 4, pp. 970-982. http:// dx.doi.org/10.1590/S0102-33062008000400008.

DIAS, J.D., SIMÕES, N.R. and BONECKER, C.C., 2012. Net cages in fish farming: a scientometric analysis. Acta Limnologica 
Brasiliensia, vol. 24, no. 1, pp. 12-17. http://dx.doi.org/10.1590/ S2179-975X2012005000022

DIAZ., TEMPORETTI, P.F. and PEDROZO, F.L., 2001. Response of phytoplankton to enrichment from Cage fish farm waste in Alicura reservoir (Patagônia, Argentina). Lakes and Reservoirs: Research and Management, vol. 6, no. 2, pp. 151-158. http:// dx.doi.org/10.1046/j.1440-1770.2001.00136.x.

FIGUEREDO, C.C. and GIANI, A., 2005. Ecological interactions between Nile Tilapia (Oreochromis niloticus, L.) and the phytoplankton community of the Furnas reservoir (Brazil). Freshwater Biology, vol. 50, no. 8, pp. 1394-1403. http://dx.doi. org/10.1111/j.1365-2427.2005.01407.x.

FONSECA, B.M. and BICUDO, C.E.M., 2011. Plankton seasonal and vertical variations in a tropical shallow reservoir with abundant macrophytes (Ninféias Pond, Brazil). Hydrobiologia, vol. 665, no. 1, pp. 229-245. http://dx.doi.org/10.1007/s10750-011-0626-3.

GORLACH-LIRA, K., PACHECO, C., CARVALHO, L.C.T., MELO JÚNIOR, H.N. and CRISPIM, M.C., 2013. The influence of fish culture in floating net cages on microbial indicators of water quality. Brazilian Journal of Biology $=$ Revista Brasileira de Biologia, vol. 73, no. 3, pp. 457-463. http://dx.doi.org/10.1590/ S1519-69842013000300001. PMid:24212684.

GUO, L. and LI, Z., 2003. Effects of nitrogen and phosphorus from fish cage-culture on the communities of a shallow lake in middle Yangtze River basin of China. Aquaculture, vol. 226, no. 1-4, pp. 201-2012. http://dx.doi.org/10.1016/S0044-8486(03)00478-2.

GUO, L., LI, Z., XIE, P. and NI, L., 2009. Assessment effects of cage culture on nitrogen and phosphorus dynamics in relation to fallowing in a shallow lake in China. Aquaculture International, vol. 17, no. 3, pp. 229-241. http://dx.doi.org/10.1007/s10499008-9195-5.

HU, R., HAN, B. and NASELLI-FLORES, L., 2013. Comparing biological classifications of freshwater phytoplankton: a case study from South China. Hydrobiologia, vol. 701, no. 1, pp. 219-233. http://dx.doi.org/10.1007/s10750-012-1277-8.

HUSZAR, V.L.M., SILVA, L.H.S., MARINHO, M., DOMINGOS, P. and SANT'ANNA, C.L., 2000. Cyanoprokaryote assemblages in eight productive tropical Brazilian waters. Hydrobiologia, vol. 424, no. 1, pp. 67-77. http://dx.doi.org/10.1023/A:1003996710416.

JEPPESEN, E., MEERHOFF, M., JACOBSEN, B., HANSEN, R., SØNDERGAARD, M., JENSEN, J., LAURIDSEN, T., MAZZEO, N. and BRANCO, C.W.C., 2007. Restoration of shallow lakes by nutrient control and biomanipulation: the successful strategy varies with lake size and climate. Hydrobiologia, vol. 581, no. 1, pp. 269-285. http://dx.doi.org/10.1007/s10750-006-0507-3.

KAGGWA, M.N., LITI, D.M. and SCHAGERL, M., 2011. Small tropical reservoirs and fish cage culture: a pilot study conducted in Machakos district, Kenya. Aquaculture International, vol. 18, no. 5, pp. 839-853. http://dx.doi.org/10.1007/s10499-010-9403-y.

KOMÁREK, J., 2003. Coccoid and colonial Cyanobacteria. In: J.D. WEHR and R.G. SHEATH, eds. Freshwater algae of North America: ecology and classification. USA: Academic Press, pp. 59-116.

KOROLEFF, K., 1976. Determination of ammonia. In: K. GRASSHOFF and E. KREMLING, eds. Methods of seawater analysis. Winhein: Verlag Chemie.

KOSTEN, S., HUSZAR, V.L.M., MAZZEO, N., SCHEFFER, M., STERNBERG, L.S.L. and JEPPESEN, E., 2009. Lake and watershed characteristics rather than climate influence nutrient limitation in shallow lakes. Ecological Applications, vol. 19, no. 7, pp. 1791-1804. http://dx.doi.org/10.1890/08-0906.1. PMid: 19831070.

KRUK, C., MAZZEO, N., LACEROT, G. and REYNOLDS, C.S., 2002. Classifications schemes for phytoplankton: a local validation of a functional approach to the analysis of species temporal replacement. Journal of Plankton Research, vol. 24, no. 9, pp. 901-912. http://dx.doi.org/10.1093/plankt/24.9.901.

LIMA, J.F., ALVES, L.R., KARPINSKI, C., PIACENTI, C.A. and PIFFER, M., 2005. A região de Salto Caxias no Sudoeste paranaense: elementos para uma política de desenvolvimento econômico microrregional. Revista Paranaense de Desenvolvimento, vol. 108, pp. 87-111.

LÓPEZ, N.L., RONDÓN, C.A.R., ZAPATA, A., JIMENÉZ, J., VILLAMIL, W., ARENAS, G., RONCÓN, C. and SÁNCHEZ, T., 2012. Factors controlling phytoplankton in tropical high-mountain drinking-water reservoirs. Limnetica, vol. 31, no. 2, pp. 305-322.

LUND, J.W.G., 1965. The ecology of the freshwater phytoplankton. Biological Reviews of the Cambridge Philosophical Society, vol. 40, no. 2, pp. 231-293. http://dx.doi.org/10.1111/j.1469185X.1965.tb00803.x.

MAACK, R., 2002. Geografia fisica do Estado do Paraná. 3rd ed. Rio de Janeiro: Livraria José Olympio. 438 p.

MACCUNE, B. and MEFFORD, M.J., 1999. PC-ORD: multivariate analysis of ecological data, version 4.0. Gleneden Blach: MjM Software Design.

MACKERETH, J.F.H., HERON, J. and TALLING, J.F., 1978. Water analysis: some revised methods for limnologists. 121 p. Ambleside: Freshwater Biological Association. Freshwater Biological Association, no. 36.

MOURA, A.N., BITTENCOURT-OLIVEIRA, M.C., DANTAS, E.W. and ARRUDA NETO, J.D.T., 2007. Phytoplanktonic associations: a tool to understanding dominance events in a tropical Brazilian reservoir. Acta Botanica Brasílica, vol. 21, no. 3, pp. 641-648. http://dx.doi.org/10.1590/S0102-33062007000300011.

NOGUEIRA, M.G., 2000. Phytoplankton composition, dominance and abundance as indicators of environmental compartmentalization in Jurumirim Reservoir (Paranapanema River), São Paulo, Brazil. Hydrobiologia, vol. 431, no. 2/3, pp. 115-128. http://dx.doi. org/10.1023/A:1003769408757.

NOGUEIRA, M.G., FERRAREZE, M., MOREIRA, M.L. and GOUVÊA, R.M., 2010. Phytoplankton assemblages in a reservoir cascade of a large tropical-subtropical river (SE, Brazil). Brazilian Journal of Biology = Revista Brasileira de Biologia, vol. 70, no. 3, suppl., pp. 781-793. http://dx.doi.org/10.1590/S151969842010000400009. PMid:21085783.

PADISÁK, J., BORICS, G., GRIGORSZKY, I. and SORÓCZKIPINTÉR, E., 2006. Use of phytoplankton assemblages for monitoring ecological status of lakes within water framework directive: the assemblage index. Hydrobiologia, vol. 553, no. 1, pp. 1-14. http://dx.doi.org/10.1007/s10750-005-1393-9.

PADISÁK, J., CROSSETTI, L.O. and NASELLI-FLORES, L., 2009. Use and misuse in the application of the phytoplankton functional classification: a critical review with updates. Hydrobiologia, vol. 621, no. 1, pp. 1-19. http://dx.doi.org/10.1007/s10750-008-9645-0.

R DEVELOPMENT CORE TEAM, 2008 [viewed 14 December 2014]. $R$ : a language and environment for statistical computing [online]. Vienna: R Foundation for Statistical Computing. Available from: http://www.R-project.org 
RANGEL, L.M., SILVA, L.H.S., ROSA, P., ROLAND, F. and HUSZAR, V.L.M., 2012. Phytoplankton biomass is mainly controlled by hydrology and phosphorus concentrations in tropical hydroelectric reservoirs. Hydrobiologia, vol. 693, no. 1, pp. 13-28. http://dx.doi.org/10.1007/s10750-012-1083-3.

REYNOLDS, C.S., 2006. Ecology of phytoplankton. Cambridge: Cambridge University Press. 535 p.

REYNOLDS, C.S., 2007. Variability in the provision and function of mucilage in phytoplankton: facultative responses to the environment. Hydrobiologia, vol. 578, no. 1, pp. 37-45. http:// dx.doi.org/10.1007/s10750-006-0431-6.

REYNOLDS, C.S., HUSZAR, V. and KRUK, C., 2002. Towards a functional classification of the freshwater phytoplankton. Journal of Plankton Research, vol. 24, no. 5, pp. 417-428. http://dx.doi. org/10.1093/plankt/24.5.417.

RIBEIRO, L.H.L., BRANDIMARTE, A.L. and KISHI, R.T., 2005. Formation of the Salto Caxias Reservoir (PR): an approach on the eutrophication process. Acta Limnologica Brasiliensia, vol. 17, no. 2, pp. 155-165.

RODRIGUES, L.C., TRAIN, S., BOVO-SCOMPARIN, V.M., JATI, S., BORSALLI, C.C. and MARENGONI, E., 2009. Interannual variability of phytoplankton in the main rivers of the Upper Paraná River floodplain, Brazil: influence of upstream reservoirs. Brazilian Journal of Biology = Revista Brasileira de Biologia, vol. 69, no. 2, suppl., pp. 501-516. http://dx.doi.org/10.1590/ S1519-69842009000300006. PMid:19738958.

SALMASO, N., NASELLI-FLORES, L. and PADISÁK, J., 2015. Functional classifications and their application in phytoplankton ecology. Freshwater Biology, vol. 60, no. 4, pp. 603-619. http:// dx.doi.org/10.1111/fwb.12520.

SANT'ANNA, C.L., GENTIL, R.C. and SILVA, D., 2006. Comunidade fitoplanctônica de pesqueiros da região metropolitana de São Paulo. In: K.E. ESTEVES and C.L. SANT'ANNA. Pesqueiros sob uma visão integrada de meio ambiente, saúde pública e manejo. São Carlos: RiMa, pp. 49-62.

SILVA, C.A., TRAIN, S. and RODRIGUES, L.C., 2005. Phytoplankton assemblages in a Brazilian subtropical cascading reservoir system. Hydrobiologia, vol. 537, no. 1-3, pp. 99-109. http://dx.doi.org/10.1007/s10750-004-2552-0.
SIPAÚBA-TAVARES, L.H., SETO, L.M. and MILLAN, R.N., 2014. Seasonal variation of biotic and abiotic parameters in parallel neotropical fishponds. Brazilian Journal of Biology $=$ Revista Brasileira de Biologia, vol. 74, no. 1, pp. 166-174. http://dx.doi. org/10.1590/1519-6984.22712. PMid:25055098.

STRICKLAND, J.D.H. and PARSONS, T.R., 1972. A pratical handbook of sea water analysis. Ottawa: Fisheries Research Board of Canada. $310 \mathrm{p}$.

SUN, J. and LIU, D., 2003. Geometric models for calculating cell biovolume and surface area for phytoplankton. Journal of Plankton Research, vol. 25, no. 11, pp. 1331-1346. http://dx.doi. org/10.1093/plankt/fbg096.

TEIXEIRA DE OLIVEIRA, M., ROCHA, O. and PERET, A.C., 2011. Structure of phytoplankton community in the Cachoeira Dourada reservoir (GO/MG), Brazil. Brazilian Journal of Biology = Revista Brasileira de Biologia, vol. 71, no. 3, pp. 587-600. PMid:21881782.

TER BRAAK, C.J.T., 1986. Canonical correspondence analysis: a new eingenvector technique for multivariate direct gradient analysis. Ecology, vol. 67, no. 5, pp. 1167-1179. http://dx.doi. org/10.2307/1938672.

TORRES, G.S., SILVA, L.H.S., RANGEL, L.M., ATTAYDE, J.L. and HUSZAR, V.L.M., 2016. Cyanobacteria are controlled by omnivorous filter-feeding fish (Nile tilapia) in a tropical eutrophic reservoir. Hydrobiologia, vol. 765, no. 1, pp. 115-129. http://dx.doi.org/10.1007/s10750-015-2406-y.

UTERMÖHL, H., 1958. Zur Vervollkommung der quantitativen Phytoplankton-Methodic. Mitteilungen Internationale Vereinigung für Theoretische und Angewandte Limnologie, vol. 9, pp. 1-38.

VOLLENWEIDER, R.A., 1968. Scientific fundamentals of the eutrophication of lakes and flowing water, with particular reference to phosphorus and nitrogen as factors in eutrophication. Paris: OECD. 159 p. Technical Report DAS/CSI/58-27.

XIAO, L.-J., WANG, T., HU, R., HAN, B.-P., WANG, S., QIAN, X. and PADISÁK, J., 2011. Succession of phytoplankton functional groups regulated by monsoonal hydrology in a large canyonshaped reservoir. Water Research, vol. 45, no. 16, pp. 5099-5109. http://dx.doi.org/10.1016/j.watres.2011.07.012. PMid:21831406. 